\title{
Sunni and Shi'ah in Cultural Acculturation (Inter- Cultural and Religious Communication of Sunni and Shia Groups in Shelters)
}

\author{
$1^{\text {st }}$ Didik Hariyanto \\ Communication Studies, Faculty of \\ Business, Law and Social Sciences, \\ Universitas Muhammadiyah Sidoarjo, \\ Sidoarjo, Indonesia \\ didikhariyanto@umsida.ac.id
}

\author{
$2^{\text {nd }}$ Djarot Meidi Budi Utomo \\ Communication Studies, Faculty of \\ Business, Law and Social Sciences, \\ Universitas Muhammadiyah Sidoarjo, \\ Sidoarjo, Indonesia
}

\author{
$3^{\text {rd }}$ Ricka Astari \\ Communication Studies, Faculty of \\ Business, Law and Social Sciences, \\ Universitas Muhammadiyah Sidoarjo, \\ Sidoarjo, Indonesia
}

\begin{abstract}
This study aims to describe and explain the cultural acculturation between the Shiite group (refugees from Sampang) with the Sunni group (local residents in Puspa Agro Sidoarjo flats). This research is based on the fact that interaction and cultural acculturation between Shiites and Sunni groups are always out of harmony. There is always a barrier that causes them to not be able to interact and communicate well, as well as cases that occur in the Sidoarjo Agro Puspa flats where Shia refugees are placed. Data collection was carried out by in-depth interviews, observations, and relevant literature studies involving two different groups living in the Puspa Agro Sidoarjo flats. The method used is Snowball Sampling. The results of this study indicate that, Cultural Acculturation that occurs between Shiite groups and Sunni groups in Puspa Agro Sidoarjo flats cannot occur properly, due to; First, there is no similarity in the concept of diversity. The difference lies in the identity of refugees as a Shiite group. Second, the difference in language used as a communication tool. Third, differences in cultural backgrounds, Shiite groups as low culture and Sunni groups as high culture. Fourth, there is no institutional or togetherness forum that can support acculturation. Negotiations The identities of Shiite groups always fail because of the negative stigma of Shiite groups against Sunni groups.
\end{abstract}

\section{Keywords-Sunni, Shi'ah, Cultural, Religion}

\section{INTRODUCTION}

Indonesia is a country rich in diversity by having diversity in ethnicity, culture, language and religion. Various differences make the motto of Unity in Diversity a unifying tool of the nation. It is not easy to unite diversity, it is necessary to unite in overcoming differences to make a harmonious whole. Likewise Diversity also needs to be interpreted as a unifying nation, accepting differences into a force and no longer a threat.The lack of tolerance may be used as one of the reasons for various conflicts with ethnic, religious, racial and intergroup backgrounds (SARA). Communal conflict between Sunni-Shiites in Sampang, began with an attack on Shiite Muslim groups by Sunni groups on Sunday, August 26, 2012 in Nanggernang Hamlet, KarangGayam Village, Omben District, Sampang, Madura around 11:00 WIB. As a result of this incident, a resident of the Shia group was declared dead, five people injured and of the four people experiencing critical conditions. In addition, Sunni Islamic groups also burned 37 houses of Shia followers in two villages, KarangGayam Village and Bluran Village, Omben District, Sampang [1]. The decision was taken by the East Java Government to move them to a more suitable place to live, namely in the Sidoarjo Agro Puspa flats. This was done so as not to take more casualties and avoid greater conflict. These flats are inhabited by two different groups namely Sunni Muslim residents who are local residents and Shiite refugees who embrace Shiite Islam. The difference between them is that Sunnis believe that the Islamic leader is the best among other Muslims. Whereas the Shia, however, argue that leadership must refer to the function of heredity, through lineages that are traced back to Muhammad SAW. The differences in age, income, education, acculturation orientation, and religious beliefs can affect the level of ethnosis. According to Brent D. Ruben Acculturation is a process that occurs when someone who socializes with new cultures and foreign cultures, migrants begin to slowly approach the similarities and differences with the environment through interconnected processes[2]. One of the concepts of acculturation on the role of religion requires a three-dimensional approach that conceptualizes religiosity in cognitive, behavioral, and emotional terms. Cognitive aspects are based on individual faith in God, behavioral aspects are the result of religious practices, rituals and prayers, and emotional aspects indicate the 
individual's psychological state of belief [3]. Shia group communication relations are exclusive in opening up communication space relations with Sunni groups.

The Shiite group in communication specifically attracted the attention of this study. First, the Shiite group does not seem to realize that exclusivity is one of the causes of the conflict in Sampang. Secondly, the Sidoarjo Agro Puspa Flats Complex, which was used as a place of refuge was also dominated by Sunni people[4]. Whereas acculturation requires intercultural communication, adaptation and placement of individual positions. So that it can increase participation in culture and shape the existence of assimilation behavior which is the goal of the acculturation process [5]. As a minority group in Indonesia, Shiites have experienced negative discrimination from both the state and the Sunni majority. Exclusion from social society is another form of discrimination accepted by Shiite groups, because Shi'a Muslims are considered deviant teachings. So that exclusivity is formed on the Shiite group and these characteristics become obstacles in conducting social relations, by limiting themselves to communication [6]. The perceptions and attitudes of Sunni-Shiite groups are the key issues of both to fight for the interests of their respective versions of religious identity and belief in Islam. As a result, the impact on the life of intra-religious communication became stalled and paralyzed among Sunni and Shia followers in Sampang, Madura [7]. The formulation of the problem in this research is How Is Intercultural and Religious Communication of Sunni and Shia Groups in the Shelter in Puspa Agro Sidoarjo Flat in the Intercultural Communication Perspective.

\section{RESEARCH METHOD}

In this study using qualitative methods using a case study approach. The selection of this method can be used to answer complex social interaction problems, problems will be solved by participating, interviews and in-depth observations of social interactions. Thus clear patterns of relationship can be found. While the approach used is a case study, which elevates case studies on intercultural and religious communication in the Sidoarjo Agro Puspa Flat as a focus of problem solving. The subject of this research is a source of data and all information used in the study. Types of data sources in this study were divided into two, namely primary and secondary data sources. The source of the observation data was conducted in the area of the Sidoarjo Agro Puspa flats and also conducted in-depth interviews with local residents and Shiite refugees as a data analysis unit. The object of this research is the communication that occurs between the Shiite groups with local residents, which is obtained from a process of indepth interviews from both parties concerned.The location of this research was conducted in the Agro Puspa Flats, Taman District, Sidoarjo Regency. The informant used in this study was to use thetechniqueSnowball Sampling. The technique used in collecting data in this study is to use the method of observation and in-depth interviews with two groups namely local residents and Shiite refugees. The collected data were analyzed using the Milles and Huberman method, data analysis consisted of three activities that occurred simultaneously namely: data reduction, data presentation and presentation of conclusions / verification [8].

\section{RESULT AND DISCUSSION}

The initial stage in conducting communication in acculturation is persona communication, the inability to use languages other than Madurese, causing them to be limited in interacting with others[9]. In persona communication there are self-image indicators obtained from local adherents mostly about negative perceptions that are pronounced on Shia refugees. The negative perception that emerges among local residents is a very dangerous form of stereotype in intercultural communication. Stereotypes are negative views or judgments given to one group of people against another group. The existence of stereotypes attached by Shiite groups with a variety of negative assessments from the public is very dangerous and at risk of undesirable events [10]. The self-image obtained from UstadIklil's statement (interview, 30 June 2019) is the assertiveness and violence of intonation in the delivery of communication by Madurese people. Rifai stated that the nature of the Madurese was very individualistic but not selfish, strongly emphasized independence, resilient and firm and frank. In the study of interculturalcommunication science is known as a low cultural context. Meanwhile, according to Edwart T. Hall said that there are two contexts in culture called low culture and high culture. Low culture is identical to the openness of information possessed by the culture along with its cultural members. While high context culture will be more closed in conveying information and communicating [11]. In a low cultural context it is positioned by Shi'ite refugees who are also Madurese, who have a Firmness and violence intonation in the delivery of communication carried out by Madurese people. This is often regarded as rude in the delivery of communication, besides that Madurese also have more horizontality in expressing their words. Then cultivation will occur with a variety of life experiences that have been undertaken by immigrants in new areas [12].

Whereas in the context of high culture is positioned by the majority of local residents as Javanese, where local residents have a high culture in conducting speech more polite and ethical. Whereas in the context of high culture it is positioned by the majority of the local population as Javanese, where the local population has a high culture in making speeches that are more polite and ethical. Shows that intercultural relations do not always lead to an increase in homogeneity in culture and behavior. And assimilation is not the most preferred or general method of acculturation, and adaptation does not become the most positive [13]. The next question asked by researchers is about the interaction between the Shiite refugees and the local residents. According to Mama Yus (Shia refugees) there is already a form of participation in carrying out activities. According to IbuMujiati (local resident), the relationship between Shiite refugees and local residents was very good. From the results of the interview above, it was found that genderfemalemore often made opportunities for acculturation, rather than gender male. The difference is caused by the ego in men, women are naturally more sincere and open in doing the potential that 
can occur acculturation. The last stage is the communication environment, researchers ask questions about what forms of participation are carried out simultaneously, they answer the anniversary of independence on August 17. After that, the researcher asked whether there was an institution or forum as a forum for unity in the flats. Each group answered no, but activities such as recitation and social gathering carried out in groups [14]. This is due to differences in the religious concepts adopted by each group. Shia-denizens are considered too exclusive in their interactions and consider outside their group to be infidels.

\section{CONCLUSION}

Based on the results of research conducted it can be concluded that the Cultural Acculturation that occurs between Shiite groups and Sunni groups can not occur properly, due to the limitations that make communication in acculturation hampered. The reason is, First, There is no equality in the concept of diversity. The difference lies in the identity of refugees as a Shiite Religion group, so the emergence of perceptions obtained from Shiite groups who consider outside their group are infidels. Second, the difference in the language context, because most Shiite refugees from Sampang Madura can only communicate in Madurese and most of them also cannot speak Indonesian. This causes difficulties in cultural acculturation. Third, the difference occurs in the culture of socializing between the two groups. Shia groups are exclusive in their interactions and prefer to gather with their own groups. Fourth, there is no institutional or togetherness forum that can support acculturation between the two groups. Negotiations The identities of Shiite groups always fail because of the negative stigma of Sunni groups against Shiite groups.

\section{ACKNOWLEDGMENTS}

We hereby thank you to Universitas Muhammadiyah Sidoarjo for Supporting the publication of this research.

\section{REFERENCES}

11] A. W. Muqoyyidin, "POTRET KONFLIK BERNUANSA AGAMA DI INDONESIA (Signifikansi Model Resolusi Berbasis Teologi Transformatif)," Anal. J. Stud. Keislam., vol. XII, no. 2, pp. 315-340, 2012.

[2] M. Deddy and J. Rakhmat, "Komunikasi Antar Budaya Panduan Berkomunikasi Dengan Orang-orang Berbeda Budaya," Bandung PT. Remaja Rosdakarya, 2006.

[3] N. Sevim, E. E. Hall, and H. M. Abu-Rayya, "The role of religion and acculturation in the consumer ethnocentrism of Turkish immigrants in Germany," Religions, vol. 7, no. 3, pp. 1-8, 2016, doi: 10.3390/rel7030029

[4] F. A. Dharma, "Kritik Terhadap Teori Spiral of Silence: Komunikasi Masyarakat Madura Dalam Konflik Sunni-Syi'Ah Di Sampang," Informasi, vol. 46, no. 1, p. 1, 2016, doi: 10.21831/informasi.v46i1.9645.

[5] D. L. Sam and J. W. Berry, "Acculturation: When Individuals and Groups of Different Cultural Backgrounds Meet," Perspect. Psychol. Sci., vol. 5, no. 4, pp. 472-481, 2010, doi: $10.1177 / 1745691610373075$

[6] I. Halimatusa'diyah, "Being Shi' ite women in Indonesia's Sunnipopulated community: Roles and relations among themselves and with others," South East Asia Res., vol. 21, no. 1, pp. 131150, 2013.

[7] R. Ida and L. Dyson, "Konflik Sunni-Syiah dan dampaknya terhadap komunikasi intra-religius pada komunitas di SampangMadura," Masyarakat, Kebud. dan Polit., vol. 28, no. 1, p. 34, 2015, doi: 10.20473/mkp.v28i12015.34-50.

[8] M. B. Milles and A. M. Huberman, "Analisis Data Kualitatif:
Buku Sumber Tentang Metode-Metode Baru," Jakarta UIP, 1992.

[9] S. W. Littlejohn and K. A. Foss, "Teori komunikasi," Jakarta: Salemba Humanika, 2009.

[10] V. Fitriani, "KOMUNIKASI ANTAR BUDAYA DALAM KEHIDUPAN PESANTREN: STUDI PADA SANTRI ETNIS JAWA, MADURA DAN NTT PONDOK PESANTREN NURUL FALAH SURABAYA," UIN Sunan Ampel Surabaya, 2013.

[11] S. Memperoleh and G. Sarjana, Komunikasi antarbudaya dalam proses akulturasi budaya (studi kasus pada mahasiswa afrika (gambia) di universitas islam negeri syarif hidayatullah jakarta). 2017.

[12] Skuza A. Jennifer, "Humanizing the Understanding of the Acculturation Experience with Phenomenology," Hum. Stud., vol. 30, no. 4, pp. 447-465, 2007, [Online]. Available: https://www.jstor.org/stable/27642813?seq=1.

[13] D. L. Sam and J. W. Berry, "Acculturation: When individuals and groups of different cultural backgrounds meet," Perspect. Psychol. Sci., vol. 5, no. 4, pp. 472-481, 2010, doi: $10.1177 / 1745691610373075$.

[14] M. v Bruinessen, "Indonesian Muslims and their place in the larger world of Islam," in 29th Indonesia Update Conference, 2011, pp. 2-31. 